\title{
Physiological Effects of Garlic Aqueous Extract on Cumin
}

Nadia A.M. El-Said and Hanan M.H. Ali

Medicinal and Aromatic Plants Research Department, Horticulture Research Institute, Agricultural Research Centre,

Cairo, Egypt.

$\mathbf{T}$

HIS WORK was carried out in the experimental farm of Medicinal and Aromatic Plants Research Department in El Kanater El Khairia, in tow successive seasons 2010/2011 and 2011/2012. The aim of this study was to investigate the effect of soaking cumin seeds before planting and spraying the plants with garlic aqueous extract $(100 \mathrm{~g} / \mathrm{L}, 200 \mathrm{~g} / \mathrm{L}$ and $400 \mathrm{~g} / \mathrm{L})$ alone or in combinations on growth, fruit yield and oil production.

Cumin plants were responded to soaking and spraying with garlic aqueous extract individually or in combinations. All treatments increased the vegetative growth expressed as (plant height, fresh and dry weights) and produced higher fruit yield compared with the control. This increment showed positive trend with increasing the garlic aqueous extract concentrations. Also, essential oil yield with the highest $p$-mentha-1-en-7-al (major component) content increased compared with the control plants.

Medicinal and aromatic plants are an important source of national income and foreign currency. They are among the most important agricultural export commodities that are in demand in USA, European and other international markets which have a major role in agriculture and industry sectors. They are the main source for safety drugs and row substances used in pharmaceuticals manufacturing.

Cumin (Cuminum cyminum L.), belongs to family Apiaceae (Umbellifera). Its one of the drug and condiment crops cumin used as popular flavoring agent in culinary, preparation bread, pastry confectionery Evans (1989) stated that cumin and volatile oil are used as an aromatic and carminative.

Fresh garlic contains $0.10-0.36 \%$ of a volatile oil composed of sulfurcontaining compounds: allicin, diallyl disulfide, diallyl trisulfide and others. The garlic volatile oil is obtained by steam distillation of crushed fresh bulbs. Some chemical components of garlic were determined by Duke (1992) in Table a. 
TABLE a. Some components in Allium sativum (Garlic) bulbs as Duke mentioned (1992).

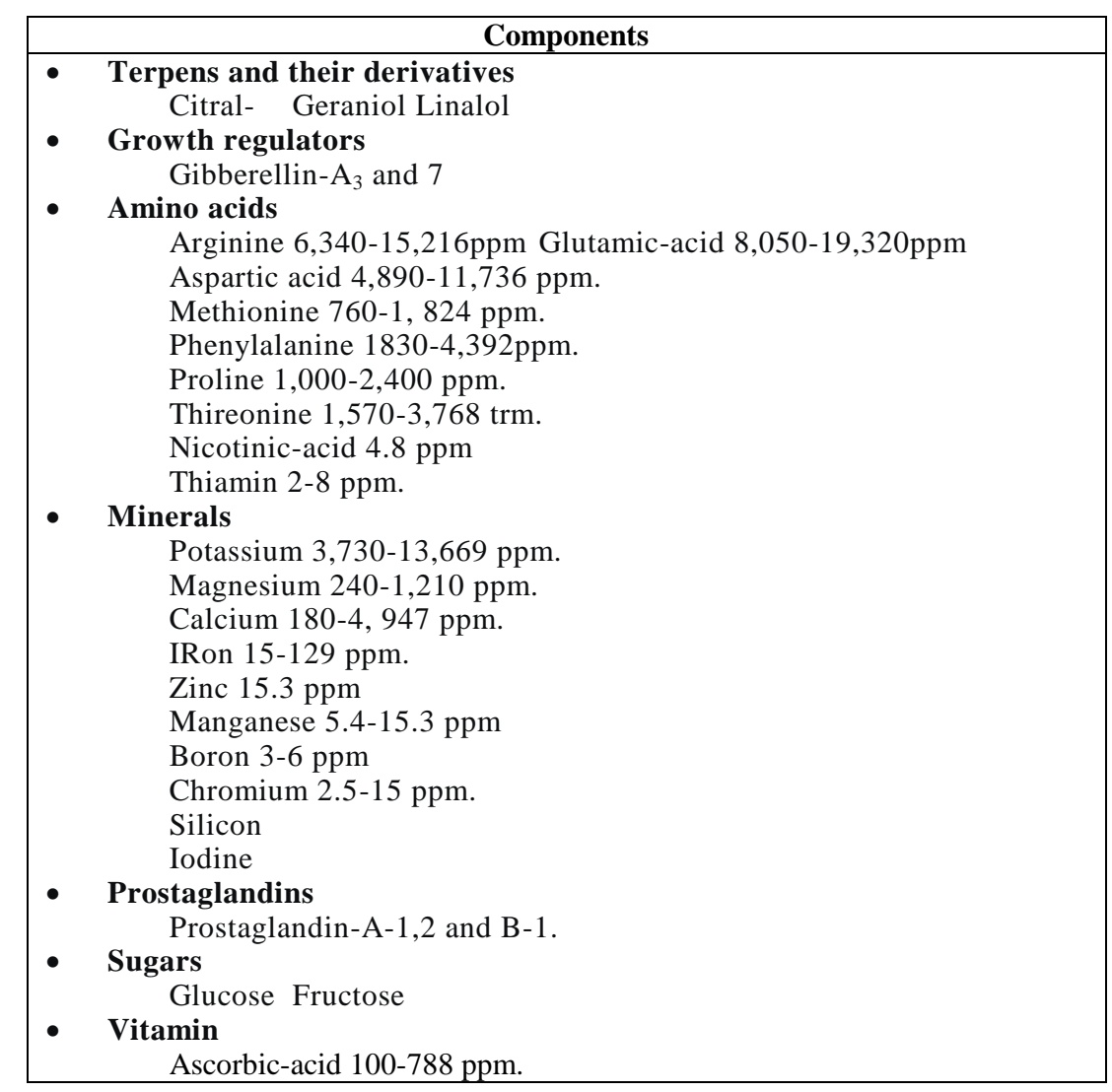

Allelopathy refers to the beneficial or harmful effects of one plant on another plant, biochemical interactions among plant as a result of one or more chemical compounds being produced by a plant plays a major role in the growth and development of some plant communities (Rice, 1984). The nature and extent to which these chemicals regulate plant growth varies according to species, the feasibility of using allelochemicals to regulate growth of certain agricultural system showed serious attention in recent years (Rice, 1984).

The fresh extracts of Allium sativum can be used to improve the vegetative growth of squash Abou-Hussein et al. (1975) and El-Desouky et al. (1998). In the same way, El-Shayeb (2009) found that, growth characters and flowering parameters of Oenthera biennis were stimulated by spraying the plants with garlic aqueous extract at $75 \%$.

The present experiment has been conducted aiming to study the physiological effects of garlic aqueous extract on the growth, fruits yield, essential oil production of cumin. 


\section{Materials and Methods}

A pot experiment was conducted at the experimental farm of Medicinal and Aromatic Plants Research Department in El Kanater El Khairia, Egypt in two successive seasons 2010/2011 and 2011/2012.

This work was designed to investigate the physiological effects of garlic aqueous extract on the vegetative growth, fruit yield and essential oil production of cumin (Cuminum cyminum L.). Fruits (seeds) were sown in plastic pots (30 $\mathrm{cm}$-diameter) on November $15^{\text {th }}$ in the two seasons. Chemical fertilizers (NPK) were added at the recommended level in three additions, the first was for all phosphorous amount which was added during soil preparation, the rest (NK) was applied in two equal doses, the $1^{\text {st }}$ one was added 30 days after sowing and the $2^{\text {nd }}$ was one month later. Garlic aqueous extract (GAE) was prepared by blending fresh mature garlic cloves in water at concentrations $100 \mathrm{~g} / \mathrm{L}, 200 \mathrm{~g} / \mathrm{L}$ and $400 \mathrm{~g} / \mathrm{L}$.Cumin seeds were equally divided to ten parts according to the treatments, 1part sown without soaking or spraying with garlic aqueous extract (control), 3 parts of seeds were sown without soaking in garlic aqueous extract, while the rest were soaked before sowing in garlic aqueous extract at concentrations of 100, 200 and $400 \mathrm{~g} / \mathrm{L}$ for 15 minutes. Plants with combination treatments ( 3 parts of seeds) were sprayed twice with garlic aqueous extract at concentrations of 100, 200 and $400 \mathrm{~g} / \mathrm{L}$. The first spray was conducted 45 days after sowing and the second was done three weeks thereafter. So, the following treatments were used:

- Control (without soaking or spraying).

- $100 \mathrm{~g} / \mathrm{L}$ (GAE) soaking.

- $200 \mathrm{~g} / \mathrm{L}$ (GAE) soaking.

- $400 \mathrm{~g} / \mathrm{L}$ (GAE) soaking.

- $100 \mathrm{~g} / \mathrm{L}$ (GAE) spraying.

- $200 \mathrm{~g} / \mathrm{L}$ (GAE) spraying.

- $400 \mathrm{~g} / \mathrm{L}$ (GAE) spraying.

- $100 \mathrm{~g} / \mathrm{L}$ (GAE) soaking + spraying.

- $200 \mathrm{~g} / \mathrm{L}$ (GAE) soaking + spraying.

- $400 \mathrm{~g} / \mathrm{L}$ (GAE) soaking + spraying.

Each treatment was replicated three times and each replicate consisted of 9 pots.

Data were recorded on growth characters at harvest date i.e. plant height, plant fresh and dry weights (g), fruit yield, essential oil percent, essential oil yield/plant $(\mathrm{ml})$ and essential oil composition.

Fruit yield/fed $=$ fruit yield/plant $\times 120000($ plant/fed $)$

The essential oil of cumin fruit was determined according to British pharmacopeia (1963).

The chemical composition of cumin essential oil of the $2^{\text {nd }}$ season were determined by gas liquid chromatography (GLC) analysis, as recommended by Hoftman (1967) and Bunzen et al. (1969). 
The experiment was designed in complete randomized blocks and the recorded data were statistically analyzed according to Snedecor and Cochran (1968), using L.S.D. at 5\%.

\section{Results and Discussion}

Effect of garlic aqueous extract on

Vegetative growth of Cumin:

Data on vegetative growth revealed that, most treatments of garlic aqueous extract significantly stimulated the vegetative growth of cumin plant in the two seasons (Table 1).

\section{Plant height $(\mathrm{cm})$}

Effect of Soaking

Generally, it was obvious that, the plants which their seeds soaked in garlic aqueous extract at all doses showed a significant increase in the plant height compared to the control in both seasons. The plant height increased gradually with increasing the dose of garlic aqueous extract. Statistically the tallest plants were obtained from those plants were soaked in garlic aqueous extract at $400 \mathrm{~g} / \mathrm{L}$.

\section{Effect of Spraying}

It was found that spraying cumin plants with garlic aqueous extract gave a positive effect on plant height in both seasons. Increasing garlic aqueous extract concentration resulted non significant increase in plant height at 100 and $200 \mathrm{~g} / \mathrm{L}$. Spraying plants with $400 \mathrm{~g} / \mathrm{L}$ produced significant effect in this respect.

\section{Effect of the combinations}

Data in Table 1 clearly emphasized that, interaction treatments gave mostly the tallest plant compared with the rest of the treatments as well as control, it was also noticed that, the interaction between soaking and spraying at $400 \mathrm{~g} / \mathrm{L}$ was found to be the most effective treatment in this respect in the two seasons.

Plant fresh weight (gm)

Data in Table 1 indicated, in general that, cumin growth showed stimulation in response to garlic aqueous extract expressed as an increment of fresh weight (g/plant).

\section{Effect of Soaking}

Regarding the effect of soaking cumin seeds in garlic aqueous extract, data in Table 1 indicated that, in the first season, increasing the concentration of garlic aqueous extract from 0 to $400 \mathrm{~g} / \mathrm{L}$ resulted insignificant increase in plant fresh weight (giving 2.96, 6.87, 8.44 and $9.41 \mathrm{~g}$ respectively. The same trend was observed in the second season, the values were $(3.27,7.67,9.07$ and $10.02 \mathrm{~g})$, respectively. 
TABLE 1. Effect of garlic aqueous extract (GAE) on vegetative growth of cumin at 2010/2011 and 2011/2012 seasons.

\begin{tabular}{|c|c|c|c|c|c|c|}
\hline \multirow{4}{*}{ Treatments } & \multicolumn{6}{|c|}{$\begin{array}{l}\text { Vegetative growth } \\
\end{array}$} \\
\hline & \multicolumn{3}{|c|}{ 2010/2011 } & \multicolumn{3}{|c|}{$2011 / 2012$} \\
\hline & \multirow{2}{*}{$\begin{array}{c}\text { Plant } \\
\text { height } \\
(\mathrm{cm})\end{array}$} & \multicolumn{2}{|c|}{ Plant weight (g) } & \multirow{2}{*}{$\begin{array}{c}\text { Plant } \\
\text { height } \\
(\mathrm{cm})\end{array}$} & \multicolumn{2}{|c|}{ Plant weight (g) } \\
\hline & & Fresh & Dry & & Fresh & Dry \\
\hline Control 0g/L (GAE) & 14.00 & 2.96 & 1.80 & 14.11 & 3.27 & 2.05 \\
\hline Soaking at $100 \mathrm{~g} / \mathrm{L}(\mathrm{GAE})$ & 19.10 & 6.87 & 3.87 & 19.67 & 7.67 & 4.22 \\
\hline Soaking at $200 \mathrm{~g} / \mathrm{L}$ (GAE) & 19.39 & 8.44 & 4.95 & 21.22 & 9.07 & 5.53 \\
\hline Soaking at $400 \mathrm{~g} / \mathrm{L}(\mathrm{GAE})$ & 20.22 & 9.41 & 5.72 & 21.89 & 10.02 & 5.87 \\
\hline Spraying at $100 \mathrm{~g} / \mathrm{L}(\mathrm{GAE})$ & 14.22 & 3.50 & 2.07 & 16.39 & 4.41 & 2.68 \\
\hline Spraying at $200 \mathrm{~g} / \mathrm{L}(\mathrm{GAE})$ & 18.72 & 4.58 & 2.81 & 18.88 & 4.92 & 2.95 \\
\hline Spraying at $400 \mathrm{~g} / \mathrm{L}(\mathrm{GAE})$ & 19.05 & 5.06 & 3.09 & 19.11 & 5.8 & 3.47 \\
\hline Soaking + Spraying at $100 \mathrm{~g} / \mathrm{L}(\mathrm{GAE})$ & 20.28 & 10.01 & 6.15 & 22.55 & 10.63 & 6.53 \\
\hline Soaking + Spraying at $200 \mathrm{~g} / \mathrm{L}(\mathrm{GAE})$ & 23.17 & 13.17 & 8.27 & 23.56 & 14.09 & 8.73 \\
\hline Soaking + Spraying at $400 \mathrm{~g} / \mathrm{L}(\mathrm{GAE})$ & 29.11 & 15.41 & 9.46 & 29.89 & 16.45 & 9.79 \\
\hline L.S.D. at $5 \%$ & 4.095 & 2.415 & 1.742 & 5.004 & 2.585 & 1.654 \\
\hline
\end{tabular}

\section{Effect of spraying}

Spraying treatments with high concentration $(400 \mathrm{~g} / \mathrm{L})$ significantly increased fresh weight of cumin plants. These increments were found to be concentration dependent i.e. increasing to high concentration of garlic aqueous extract resulted in increasing the fresh weight of cumin plants $(5.062,5.80 \mathrm{~g} / \mathrm{plant})$ in the two seasons respectively.

\section{Effect of combinations}

Actually, data in Table 1 clearly emphasized a promotion of cumin growth due to the combination treatments values were significantly higher than those of the control in the two seasons. The combination treatment of soaking and spraying garlic aqueous extract at the highest dose $(400 \mathrm{~g} / \mathrm{L})$ gave the highest values 15.41 and $16.45 \mathrm{~g} /$ plant and the same effect was recorded in case of the interaction between spraying and soaking garlic aqueous extract at $(200 \mathrm{~g} / \mathrm{L})$ (13.17 and $14.09 \mathrm{~g} / \mathrm{plant})$ in comparison with controls (2.96 and $3.27 \mathrm{~g} / \mathrm{plant})$ in both seasons respectively.

\section{Plant dry weight (gm)}

Effect of soaking

Data presented in Table 1 showed that, cumin seeds soaked in garlic aqueous extract at the highest dose $(400 \mathrm{~g} / \mathrm{L})$ gave the higher values of dry weight per plant (5.72 and $5.87 \mathrm{~g} / \mathrm{plant})$, followed by soaking the seeds in garlic aqueous extract at $200 \mathrm{~g} / \mathrm{L}$ which gave (4.95 and $5.53 \mathrm{~g} / \mathrm{plant}$ ), respectively in the two seasons. The differences between these two treatments were not significant in the two seasons.

\section{Effect of spraying}

The dry weight increased gradually with increasing the concentration of garlic aqueous extract in the two seasons. The heavier dry weights 3.09, 3.47, 
2.81 and $2.95 \mathrm{~g}$ are observed as a result of spraying the plants with garlic aqueous extract at $400 \mathrm{~g} / \mathrm{L}$ and $200 \mathrm{~g} / \mathrm{L}$ respectively. It was of interest to indicate that these two treatments gave mostly the same effect in this respect.

\section{Effect of the combinations}

Data in Table 1 recorded that, the interaction treatments showed significant effect on plant dry weight in the two seasons. The combination of spraying and soaking garlic aqueous extract at the highest dose $(400 \mathrm{~g} / \mathrm{L})$ resulted in the heaviest dry weights $(9.46$ and $9.79 \mathrm{~g} / \mathrm{plant})$ in both seasons respectively. Moreover, data also emphasized that the combination treatments of the medium concentration $(200 \mathrm{~g} / \mathrm{L})$ produced the same effect previously showed in case of the highest concentration $(400 \mathrm{gm} / \mathrm{L})$ of the combination treatments.

In general these results are in agreement with that obtained by El-Desouky et al. (1998) they reported that soaked squash (Cucurbita pepo) seeds on garlic extract at concentrations of 50,250 or $500 \mathrm{ml} / \mathrm{L}$ significantly increased stem length and dry weight of stem and leaves. Nour El-Din (2005) found that the spraying Majorana hortensis with garlic aqueous extract at 25, 50 or $100 \%$ concentrations increased plant height, number of branch per plant, fresh weight of herb per plant (g) and dry weight per plant (g). Also, El-Shayeb, (2009) on Oenothera biennis, stated that spraying aqueous extract at $75 \%$ was more effective in stimulating growth and produced the maximum response in this respect.

\section{Fruit yield of Cumin}

It is evident that most treatments have positive effect on fruit yield in both seasons. The difference between the high concentration and the control are highly significant Table 2 .

\section{Effect of soaking}

Soaking cumin seeds in garlic extract at the different concentrations significantly increased fruit yield/plant and fruit yield/fed compared with control in both seasons.

The higher fruit yield/plant and fruit yield/fed were detected in seeds soaked in garlic aqueous extract at $400 \mathrm{~g} / \mathrm{L}$. The values were $4.49 \mathrm{~g} / \mathrm{plant}$ and 538.80 $\mathrm{kg} / \mathrm{fed}$, respectively in the first season and $4.60 \mathrm{~g} / \mathrm{plant}$ and $552.40 \mathrm{~kg} / \mathrm{fed}$, respectively in the second one. The same results were also showed in case of $200 \mathrm{~g} / \mathrm{L}$ treatment.

\section{Effect of spraying}

In Table 2, it can be notice that spraying garlic extract increased fruit yield plant and fruit yield/fed over control in both seasons. Increasing the concentration of garlic extract gradually increased the fruit yield in the two seasons. It was also noticed that, the medium rate of $200 \mathrm{~g} / \mathrm{L}$ garlic extract gave the same effect of the highest rate $(400 \mathrm{~g} / \mathrm{L})$. The values were $2.10 \mathrm{~g} / \mathrm{plant}$ and $252.00 \mathrm{~kg} / \mathrm{fed}$ and 2.22 $\mathrm{g} / \mathrm{plant}$ and $266.40 \mathrm{~kg} / \mathrm{fed}$ in the first and second season respectively.

Egypt. J. Hort. Vol. 40, No.2 (2013) 


\section{Effect of combinations}

The combination treatments of soaking and spraying also significantly increased fruit yield/plant and fruit yield/fed in the two seasons. Increasing garlic extract up to $400 \mathrm{~g} / \mathrm{L}$ increased the values in this concern comparing to the other treatments of garlic extract in both seasons.

TABLE 2. Effect of garlic aqueous extract (GAE) on fruit yield of cumin 2010/201 and 2011/2012 seasons.

\begin{tabular}{|l|c|c|c|c|}
\hline \multirow{2}{*}{ Treatments } & \multicolumn{4}{c|}{ Fruit yield } \\
\cline { 2 - 5 } & \multicolumn{2}{|c|}{$\mathbf{2 0 1 0 / 2 0 1 1}$} & \multicolumn{2}{c|}{$\mathbf{2 0 1 1 / 2 0 1 2}$} \\
\cline { 2 - 5 } & Plant $(\mathbf{g})$ & Fed $(\mathbf{k g})$ & Plant $(\mathbf{g})$ & Fed $(\mathbf{k g})$ \\
\hline Control 0 $(\mathrm{GAE})$ & 1.35 & 162.40 & 1.57 & 188.00 \\
\hline Soaking at 100g/L $(\mathrm{GAE})$ & 2.89 & 344.40 & 3.07 & 368.00 \\
\hline Soaking at 200g/L $(\mathrm{GAE})$ & 3.80 & 454.00 & 4.35 & 522.40 \\
\hline Soaking at 400g/L $(\mathrm{GAE})$ & 4.49 & 538.80 & 4.60 & 552.40 \\
\hline Spraying at 100g/L $(\mathrm{GAE})$ & 1.50 & 180.40 & 1.95 & 234.40 \\
\hline Spraying at 200g/L $(\mathrm{GAE})$ & 2.10 & 252.00 & 2.22 & 266.40 \\
\hline Spraying at 400g/L $(\mathrm{GAE})$ & 2.30 & 276.40 & 2.51 & 301.20 \\
\hline Soaking + Spraying at 100g/L $(\mathrm{GAE})$ & 4.87 & 584.00 & 5.17 & 620.40 \\
\hline Soaking + Spraying at 200g/L $(\mathrm{GAE})$ & 6.63 & 796.00 & 6.95 & 833.60 \\
\hline Soaking + Spraying at 400g/L $(\mathrm{GAE})$ & 7.47 & 896.80 & 7.57 & 908.80 \\
\hline L.S.D. at 5\% & 1.613 & 180.45 & 1.629 & 198.20 \\
\hline
\end{tabular}

However, it is of important to report that the garlic extract of 400 and 200 $\mathrm{g} / \mathrm{L}$ produce the same effect in cumin growth and fruit yield so, the differences between the values of fruit yield per plant and per feddan were found to be insignificant in the two seasons.

Similar results were observed by Meena et al. (2011) on Brassica juncea. They stated that spraying the plants with garlic aqueous extract significantly increased seed yield compared to control.

\section{Essential oil Production}

Data presented in Table 3 showed that garlic aqueous extract slightly increased volatile oil percentage in both two seasons. These increment was insignificant in the first season. However in the second season garlic aqueous extract had a significant effect on oil percentage compared to untreated plant.

Oil yield/plant and oil yield/fed of cumin plants were positively affected by soaking and spraying garlic aqueous extract alone or in combinations.

\section{Effect of soaking}

Garlic aqueous extract application had no significant effect on volatile oil percentage, in the first season, however, the plants treated with garlic aqueous extract at $400 \mathrm{~g} / \mathrm{L}$ gave the highest essential oil percentage $(3.57 \%$ ) followed by plants treated with garlic aqueous extract at $200 \mathrm{~g} / \mathrm{L}$. In the second season, garlic aqueous extract at 100, 200, $400 \mathrm{~g} / \mathrm{L}$ significantly increased essential oil 
percentage in comparison with control. Soaking cumin seeds in garlic aqueous extract at $400 \mathrm{~g} / \mathrm{L}$ gave the highest volatile oil percentage $4.17 \%$ followed by $200 \mathrm{~g} / \mathrm{L}$ compared to control.

Soaking cumin seeds in garlic extract significantly increased, volatile oil yield/plant and volatile oil yield/fed compared to the control in the two seasons. The maximum value was found with the highest concentration of garlic $(400 \mathrm{~g} / \mathrm{L})$. The values were $0.160 \mathrm{ml} / \mathrm{plant}$ and $19.20 \mathrm{~L} / \mathrm{fed}$ respectively in the first season and $0.190 \mathrm{ml} / \mathrm{plant}$ and $22.84 \mathrm{~L} /$ fed, respectively in the second one. The results also indicated that, the medium concentration of garlic aqueous extract $200 \mathrm{~g} / \mathrm{L}$ gave the same effect of the highest concentration.

\section{Effect of spraying}

Spraying garlic aqueous extract slightly increased volatile oil percentage of cumin. Spraying garlic aqueous extract at $400 \mathrm{~g} / \mathrm{L}$ gave the highest oil percentage followed by $200 \mathrm{~g} / \mathrm{L}$. in the two seasons. These increment was insignificant in the first season compared with control.

Spraying aqueous garlic extract from $100 \mathrm{~g} / \mathrm{L}$ to $400 \mathrm{~g} / \mathrm{L}$ significantly increased essential oil yield/plant and oil yield/fed compared to control in both seasons. The higher records in this concern were $0.078, \mathrm{ml} / \mathrm{plant}$ and $9.32 \mathrm{~L} / \mathrm{fed}$, respectively in the first season, and $0.088 \mathrm{ml} / \mathrm{plant}$ and $10.60 \mathrm{~L} / \mathrm{fed}$, respectively in the second one were obtained from spraying garlic extract at $400 \mathrm{~g} / \mathrm{L}$. It was also noticed that the medium concentration of $200 \mathrm{~g} / \mathrm{L}$ gave mostly the same effect of the highest one. These results were similar to that obtained by Nour ElDin (2005) on Majorana hortensis.

TABLE 3. Effect of garlic aqueous extract (GAE) on essential oil production of cumin plant at 2010/2011 and 2011/2012 seasons.

\begin{tabular}{|c|c|c|c|c|c|c|}
\hline \multirow{4}{*}{ Treatments } & \multicolumn{6}{|c|}{ Essential oil production } \\
\hline & \multicolumn{3}{|c|}{$2010 / 2011$} & \multicolumn{3}{|c|}{$2011 / 2012$} \\
\hline & \multirow{2}{*}{ Percentage } & \multicolumn{2}{|c|}{ Oil yield } & \multirow{2}{*}{ Percentage } & \multicolumn{2}{|c|}{ Oil yield } \\
\hline & & $\mathrm{ml} /$ plant & L/fed & & $\mathrm{ml} /$ plant & L/fed \\
\hline Control 0 (GAE) & 2.50 & 0.033 & 4.08 & 2.60 & 0.042 & 5.00 \\
\hline Soaking at $100 \mathrm{~g} / \mathrm{L}(\mathrm{GAE})$ & 3.43 & 0.101 & 12.08 & 3.83 & 0.124 & 14.88 \\
\hline Soaking at $200 \mathrm{~g} / \mathrm{L}(\mathrm{GAE})$ & 3.47 & 0.131 & 15.68 & 3.90 & 0.172 & 20.68 \\
\hline Soaking at $400 \mathrm{~g} / \mathrm{L}(\mathrm{GAE})$ & 3.57 & 0.160 & 19.20 & 4.17 & 0.190 & 22.84 \\
\hline Spraying at $100 \mathrm{~g} / \mathrm{L}(\mathrm{GAE})$ & 2.97 & 0.045 & 5.36 & 3.07 & 0.060 & 7.16 \\
\hline Spraying at $200 \mathrm{~g} / \mathrm{L}(\mathrm{GAE})$ & 3.10 & 0.065 & 7.76 & 3.33 & 0.070 & 8.40 \\
\hline Spraying at $400 \mathrm{~g} / \mathrm{L}(\mathrm{GAE})$ & 3.40 & 0.078 & 9.32 & 3.50 & 0.088 & 10.60 \\
\hline Soaking + Spraying at $100 \mathrm{~g} / \mathrm{L}(\mathrm{GAE})$ & 3.60 & 0.174 & 20.88 & 4.30 & 0.224 & 26.84 \\
\hline Soaking + Spraying at $200 \mathrm{~g} / \mathrm{L}(\mathrm{GAE})$ & 3.73 & 0.254 & 30.48 & 4.33 & 0.301 & 36.12 \\
\hline Soaking + Spraying at $400 \mathrm{~g} / \mathrm{L}(\mathrm{GAE})$ & 3.97 & 0.298 & 35.76 & 4.43 & 0.333 & 39.92 \\
\hline L.S.D. at 5\% & NS & 0.076 & 8.94 & 0.873 & 0.076 & 9.07 \\
\hline
\end{tabular}

Egypt. J. Hort. Vol. 40, No.2 (2013) 


\section{Effect of the combinations}

Regarding the interaction effect between soaking and spraying, there was no significant effect on essential oil percentage in the first season. However the interaction between soaking and spraying was more effective in increasing, volatile oil yield/plant and oil yield/fed than each of them alone. The highest, oil yield $0.298 \mathrm{ml} /$ plant and oil yield/fed $35.76 \mathrm{~L} / \mathrm{fed}$, respectively in the first season and $0.333 \mathrm{ml} / \mathrm{plant}$ and $39.92 \mathrm{~L} / \mathrm{fed}$, respectively in the second one were obtained from the highest concentration of garlic extract $400 \mathrm{~g} / \mathrm{L}$. It was also observed that values of oil yield per plant and per fed. of medium concentration $(200 \mathrm{~g} / \mathrm{L})$ were not different than that of the highest one in the two seasons.

\section{Chemical composition of essential oil}

Table 4 and Fig. (1-10) showed that, GLC analysis of cumin volatile oil revealed that $p$-mentha-1-en-7-al was the main component. These results agreed those of Nicola S. Iacobellis et al. (2005) reported that the main component of cumin oil is $p$-mentha-1-en-7-al. In this regard Karim et al. (1976) found that, ecological conditions of 2 regions affected the oil composition of pakistan Cumin seed and indicated by the variations in hydrocarbon fraction, $\beta$-pinene and y-terpinene were the major terpenes in both oils 33.3 and $41.1 \%$, P-cymene was present to the extent of $6 \%$ in one and only 2.740 in the other. The content of oxygenated terpenes cumin aldehyde and cumin alcohol was quite high (22.4 and $20 \%)$ and $(7.2$ and $3.7 \%$ ) respectively.

\section{Effect of soaking}

Generally, soaking cumin plants in garlic aqueous extract at different concentrations (100, 200 and $400 \mathrm{~g} / \mathrm{L})$ increased $p$-mentha-1-en-7-al percentages in the first and second seasons compared to untreated plants.

Effect of spraying

From Table 4, it could be noticed that spraying cumin plants with garlic aqueous extract at 100, 200 and $400 \mathrm{~g} / \mathrm{L}$ increased $p$-mentha-1-en-7-al percentage compared to the control.

\section{Effect of the combinations}

Combined treatments of soaking and spraying were more effective in increasing $p$-mentha-1-en-7-al in cumin volatile oil than each of them alone. Increasing the concentration of garlic extract from 100 to $400 \mathrm{~g} / \mathrm{L}$ increased $p$-mentha-1-en-7-al in cumin oil, the maximum value $(45.54 \%)$ was obtained from the highest concentration of garlic extract $(400 \mathrm{~g} / \mathrm{L})$ followed by the rest concentration of 100 and $200 \mathrm{~g} / \mathrm{L}$ of the combination treatments .

It could be concluded that interaction between spraying and soaking garlic extract was more effective in stimulating cumin growth, fruit yield, oil production and the main component of cumin oil. This may be a result of containing garlic extract of various active components like allicin and its derivatives S-allyl cysteine, diallyldisulfide according to Ghalehkandi et al. (2012). Allicin and other thiosulphinates found in garlic have a Wide spectrum 
of antimicrobial activity and this is probably due to the thiosulphinate reacting with thiol groups of various bacterial enzymes ( Ankri and Mirelman 1999).This components may be affect physiological metabolism in cumin plants (Duke,1992). These results agreed with those of Croteau and Loomis (1974) they came to the conclusion that, physiological factors may significantly affected the composition of terpenes produced in any given environment.

TABLE 4. Effect of garlic aqueous extract (GAE) on essential oil component contents in the second season $(2011 / 2012)$ in cumin seeds.

\begin{tabular}{|l|c|c|c|c|c|}
\hline Treatments & $\boldsymbol{\alpha}$ Thujene & $\boldsymbol{\beta}$ - Pinene & $\boldsymbol{\alpha}$-phyllendrene & $\begin{array}{c}\text { Cumin } \\
\text { ldehyde }\end{array}$ & $\begin{array}{c}\boldsymbol{P} \text {-mentha- } \\
\text { 1-en-7-al }\end{array}$ \\
\hline Control 0 (GAE) & 5.74 & 8.75 & 16.68 & 27.83 & 41.01 \\
\hline Soaking at 100g/L(GAE) & 5.74 & 5.13 & 21.04 & 24.34 & 43.75 \\
\hline Soaking at 200g/L(GAE) & 6.57 & 5.42 & 15.63 & 28.61 & 43.77 \\
\hline Soaking at 400g/L(GAE) & 5.97 & 6.57 & 18.07 & 25.55 & 43.84 \\
\hline Spraying at $100 \mathrm{~g} / \mathrm{L}(\mathrm{GAE})$ & 9.20 & 3.67 & 17.82 & 26.87 & 42.45 \\
\hline Spraying at 200g/L(GAE) & 9.18 & 4.25 & 17.65 & 26.07 & 42.85 \\
\hline Spraying at 400g/L(GAE) & 5.05 & 7.83 & 18.27 & 25.67 & 43.19 \\
\hline Soaking+ Spraying at 100g/L(GAE) & 7.44 & 4.56 & 20.55 & 23.13 & 44.32 \\
\hline Soaking + Spraying at 200g/L(GAE) & 7.44 & 4.56 & 20.55 & 23.13 & 44.32 \\
\hline Soaking + Spraying at 400g/L(GAE) & 6.25 & 8.05 & 20.23 & 19.92 & 45.54 \\
\hline
\end{tabular}

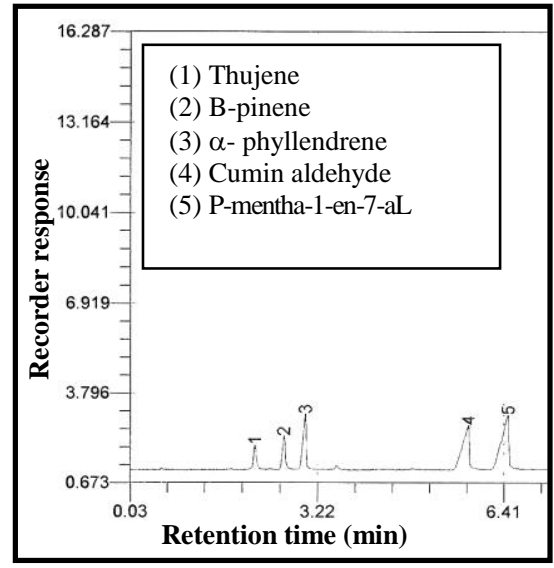

Fig.1.Chromatogram of cumi essential oil (control) .

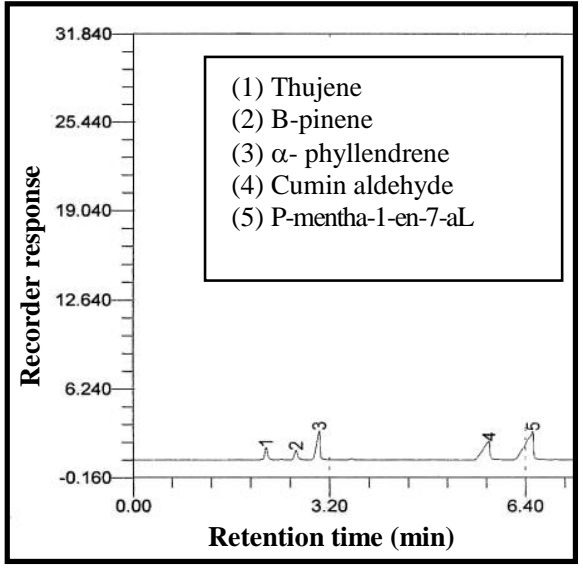

Fig. 2. Chromatogram of cumin essential oil (Soaking at 100g/L) . 


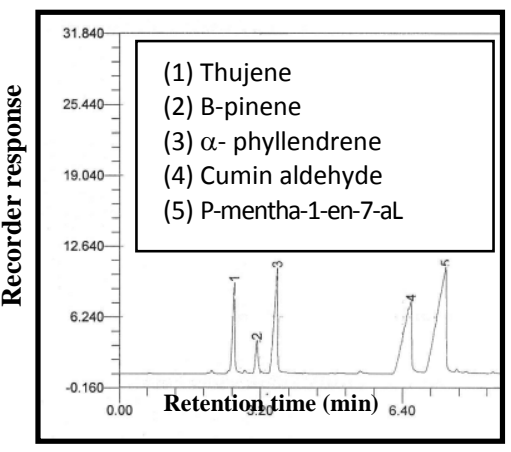

Fig. 3. Chromatogram of cumin essential oil (Soaking at 200g/L) .

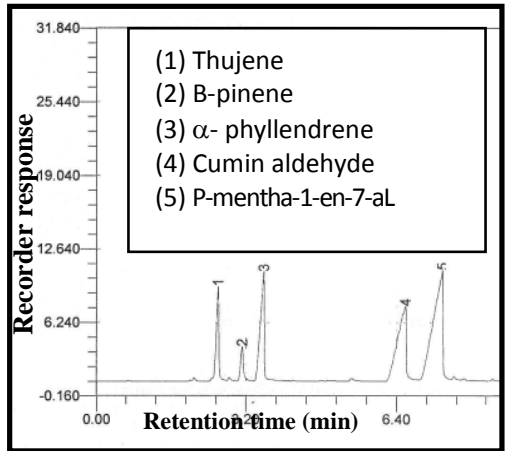

Fig. 5. Chromatogram of cumin essential oil (Soaking at $100 \mathrm{~g} / \mathrm{L})$.

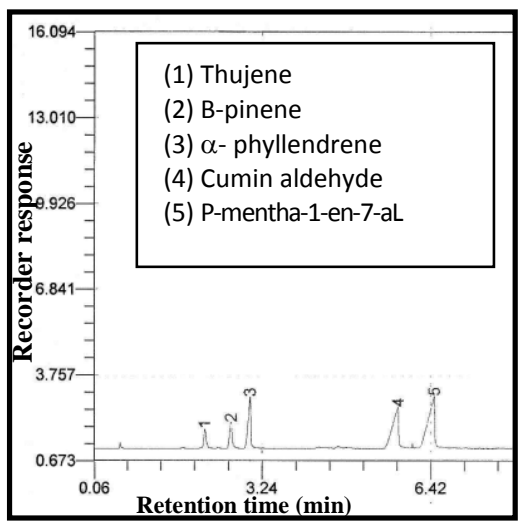

Fig. 7. Chromatogram of cumin essential oil (Soaking at $400 \mathrm{~g} / \mathrm{L})$.

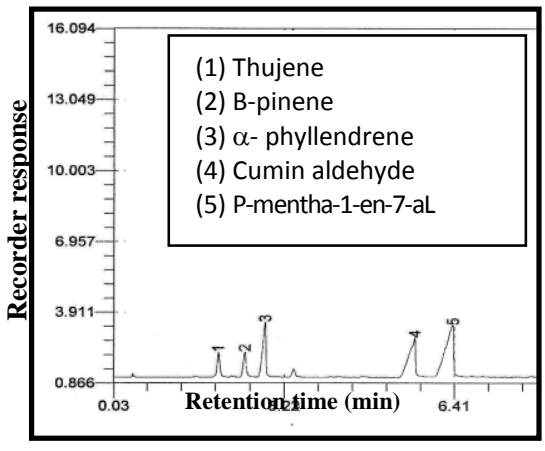

Fig. 4. Chromatogram of cumin essential oil (Soaking at $400 \mathrm{~g} / \mathrm{L}$ ) .

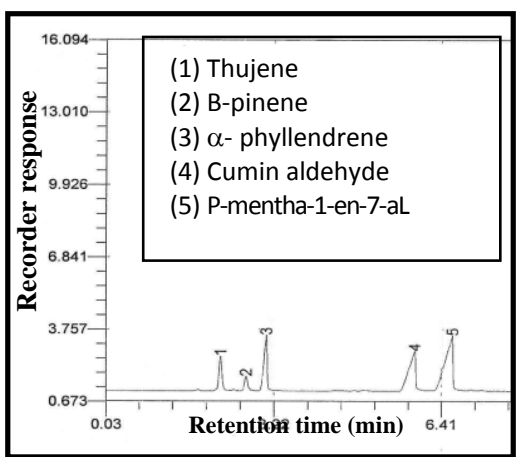

Fig. 6. Chromatogram of cumin essential oil (Soaking at 200g/L) .

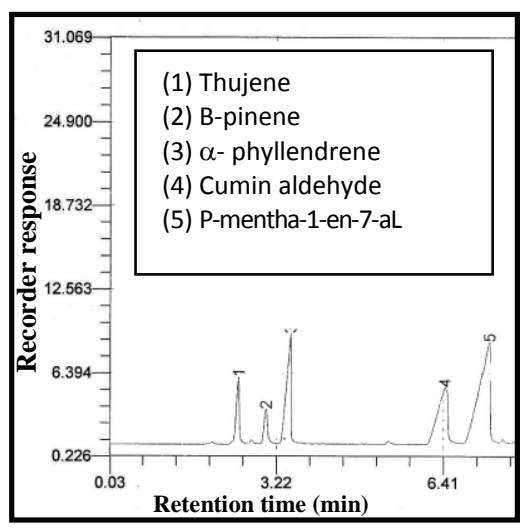

Fig. 8. Chromatogram of cumin essential oil (Soaking and Spraying at $100 \mathrm{~g} / \mathrm{L}$ ) .

Egypt. J. Hort. Vol. 40, No.2 (2013) 


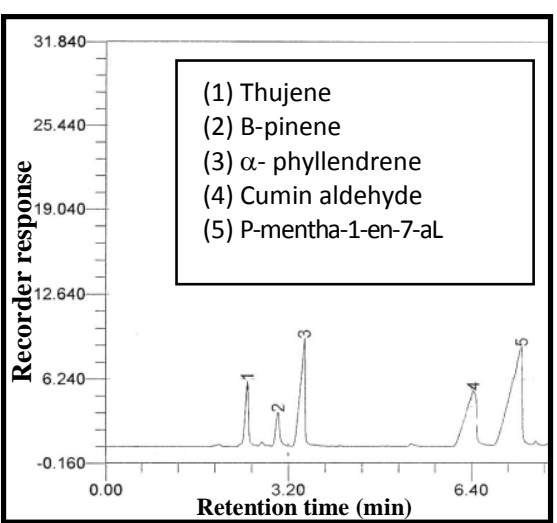

Fig. 9. Chromatogram of cumin essential oil (Soaking and Spraying at 200g/L) .

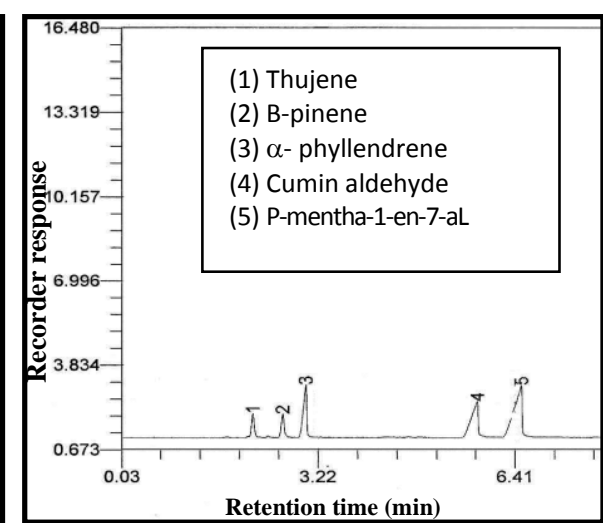

Fig. 10. Chromatogram of cumin essential oil (Soaking and Spraying at $400 \mathrm{~g} / \mathrm{L})$.

\section{Recommendation}

It could be recommended cumin farmers to use garlic aqueous extract at $200 \mathrm{~g} / \mathrm{L}$ (soaking the cumin seeds before sowing and spraying twice during the growing season), to obtain the highest growth, fruit yield and essential oil yield as well as the highest essential oil quality of cumin. This approach may led to strengthen and expanding the using of natural extracts of medicinal and aromatic plants in other purposes (in addition to therapeutics uses) due to its richness of different physiologically active compounds (allelochemicals) that have allelopathic effects and may affect in a good manner plant growth.

\section{References}

Abou-Hussein, M.R., Fadi, M.S. and Wally, Y.A. (1975) Effect garlic bulb crude extract on flowering, sex ratio and yield of squash, Egyptian Journal of Horticulture, 2(1), 129-130.

Ankri, S. and Mirelman, A. (1999) Antimicrobial properties of allicin from garlic. Microbes Infect., 2, 125-129

British Pharmacopeia (1963) The Pharmaceutical, press 17 bloomsbury square, London W.C.L.

Bunzen, J.N., Guichard, J. Labbe, P. Prevot, J. Sperpinetand, J. and Tranchant, J. (1969) Practical manual of Gas Chromatography. J.Tranchant (Ed.), El-Seivier Publ.Co., Amesterdam-London.

Croteau, R. and Loomis, W. D. (1974) Biosynthesis and metabolism of monoterpenes. Symposium on natural flavoring materials. $15^{\text {th }}$. Annual Meeting of the society for Economic Botany July 8-10 1974 . Kellogg center. Michigan State Univ. U.S.A. 
Duke, J. A. (1992) Handbook of Phytochemical Constituents of GRAS Herbs and Others Economic Plants. Boca Raton FL. CRC Press.

El-Desouky, S.A., Wanas, A.I.A. and Khedr, Z.M.A. (1998) Utilization of some natural plant extracts (of garlic \& yeast) as seed-soaked materials to squash (Cucurbita Pepo). Effect of growth sex expression and fruit yield \& quality. Annals of Agric. Sci, Moshtohor, 36(2), 829-854.

El-Shayeb, N.S.A. (2009) Physiological studies on Oenothera biennis Ph.D. Thesis of Ornamental Horticulture Department Faculty of Agriculture at Moshtohor Zagazig University (Banha Branch).

Evans, W.C. (1989) Rtease and Evans, Pharmacoginosy. $13^{\text {th }}$ ed. English Language Book. Society Baliliere Tindail p. 440.

Ghalehkandi, J.G., Ebrahimnezhad, Y., and Nobar, R.S. (2012) Effect of garlic (Allium sativum) aqueous extract on serum values of urea, uric acid and creatinine compared with chromium chloride in male rats. Annals of Biological Research, 3 (9), $4485-4490$

Hoftman, E. (1967) Chromatography $2^{\text {nd }}$ ed., Reinhold Publ. Corp., 208-515.

Karim, A., Parvez, M. and Bhatty, M.K. (1976) Studies on the essential oils of the Pakistan species of family umbelli fereae. Part II: Cuminum cyminum Linn. Seed oil pak. J. Sci. Ind. Res., 19 (5-6), 239-242.

Meena, P.D., Awasthi, R.P., Shailesh Godika, Gupta, J.C., Ashok Kumar, Sandhu, P.S., Pankaj Sharma, Rai, P.K., Singh, Y.P, Rathi, A.S., Rajendra Prassad, Dinesh Rai and Kolte, S.J. (2011) Eco-friendly approaches managing major diseases of Indian mustard. World Applied Sciences Journal, 12(8), 1192-1195.

Nicola, S. Iacobellis, Pietro Lo Contore, Francesco Capasso and Felice Sentatore (2005) Antibacterial activity of Cuminum cyminum and Carum carvi essential oils. J. Agric. Food Cehm, 53, 57-61.

Nour El-Din, T. (2005) Physiological studies on marjoram plants (Majorana hortensis).

Rice, F. L. (1984) Allelopathy. $2^{\text {nd }}$ ed., F. D. Academic Press, Inc., Orlando, FI 422 p.

Snedecor, G.W. and Conchran, W.G. (1968) Statistical Methods. The Iowa State Univ. Pres, Ames, Iowa, U.S.A.

(Received 4 / 8 /2013;

accepted 31/10/2013) 


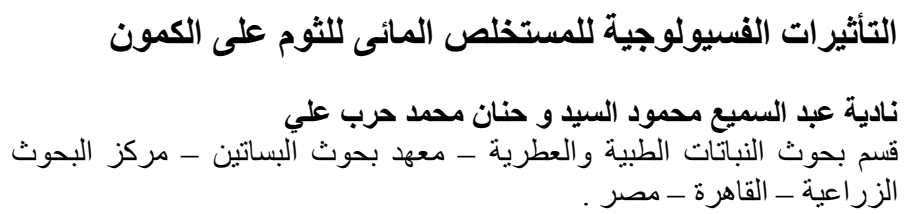

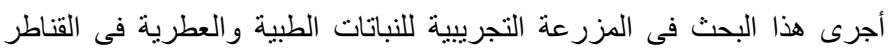

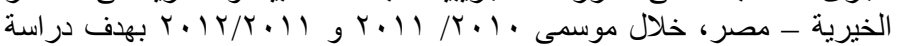

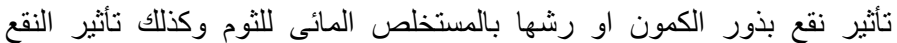

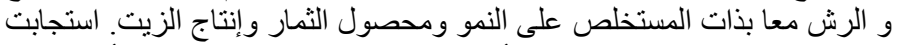

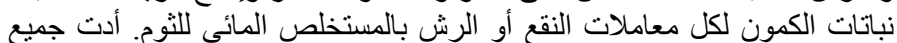

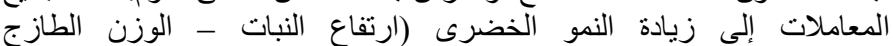

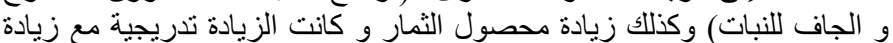

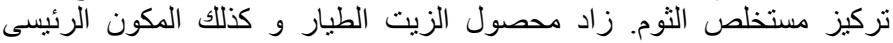
فى الزيت الطيار بالمقارنه بالكنترول الطيار (p-mentha-1-en-7-al) 